Theodore R. Weeks

\title{
Antisemitism in the Polish Lands
}

Małgorzata Domagalska, Zatrute ziarno: Proza antysemicka na tamach "Roli" (1883-1912), Warsaw: Wydawnictwo Neriton, 2015, 341 pp.

Grzegorz Krzywiec, Polska bez Żydów: Studia z dziejów idei, wyobrażeń i praktyk antysemickich na ziemiach polskich początku XX wieku (1905-1914), Warsaw: Instytut Historii PAN, 2017, 559 pp.

Maciej Moszyński, Antysemityzm w Królestwie Polskim: Narodziny nowoczesnej ideologii antyżydowskiej (1864-1914), Poznań: Instytut Historii UAM, 2017, 468 pp.

At the beginning of the twentieth century, Poland-not an independent country yet, but nonetheless existing in the minds of Polish patriots-had the largest concentrations of Jews on earth. At the end of the Second Polish Republic (1939), only the USSR and the USA boasted larger Jewish populations, and many of these had origins or roots in the Polish lands. Hence, it is inconceivable to speak of "Polish history" without including Jews. And, unfortunately, it is also not possible to discuss modern Polish history honestly without examining the phenomenon of antisemitism. Each of these books discusses, analyzes, and explains the development of anti-Jewish ideology and practices in the Polish lands before 1914. And all three of these books make a serious and valuable contribution to our understanding of this phenomenon and, hence, to Polish history. 
These are quite different studies that approach "antisemitism" (a flawed and ambiguous term at best) from different perspectives. To be sure, all three concentrate primarily on the Kingdom of Poland and use the press as a major source. As a literary scholar, Domagalska analyzes antisemitic prose in the notorious periodical Rola, while Moszyński and Krzywiecboth historians-look at how this ideology developed and gained dominance in the late nineteenth and early twentieth century. All three studies speak primarily to the specialist but could be read with profit by anyone interested in Polish or Jewish history.

Maciej Moszyński's Antysemityzm w Królestwie Polskim [Antisemitism in the Kingdom of Poland], a re-working of his doctoral dissertation, casts the broadest net chronologically and thematically. Basing his research primarily on a close reading of Rola and other works by this periodical's notorious editor, Jan Jeleński, Moszyński provides an excellent overview of how modern antisemitism took shape in the Polish lands after 1863. While the author centers his study on Jeleński and Rola, his argumentation is informed by a broad and deep reading of other contemporary periodicals, including Gtos, Prawda, Gazeta Poranna 2 Grosze, and Przeglad Katolicki. By comparing the treatment of the "Jewish question" in Rola with other contemporary periodicals, Moszyński is able to show the influence of Rola's ideology on others and, conversely, demonstrate how Jeleński's view of the Jewish question changed over time.

Initially (in the 1860s and early 1870s), as Moszyński points out, Jan Jeleński had not yet developed into a full-blown antisemite. To be sure, even in this period the future editor of Rola saw the Jews as a problem. Still, his solution to this "problem" remained within the limits, more or less, of the positivists' proposals to make Jews "productive" and to integrate them into Polish society. While this argument is not new, previous scholars have not developed the chronology of Jeleński's thinking in such detail. And, of course, Jeleński's anti-Jewish ideology was always linked to religious as well as sociological and economic arguments. Moszyński takes us step by step from one early work (brochures, really) to another, demonstrating how Jeleński's ideology developed in a direction of emphasizing the unique and then almost exclusive threat from Jews, even taking on a quasi-racial tone when discussing them. This development was crowned by the founding of Rola in 1883. This period of Jeleński's career takes up 
more than one third of the book, with a degree of close focus lacking in previous research.

As is fairly well known, the first ideological antisemites on the Polish lands had their center with Rola. Moszyński shows how this circle of writers developed, influences from abroad (in particular, Teofil Merunowicz in Galicia), controversies with other periodicals like Prawda, Wiek, and Przeglad Katolicki (and others), and the growing influence of Rola's ideas after the turn of the century. Rola's anti-Jewish and anti-capitalist arguments dovetailed nicely with those of foreign commentators such as August Rohling, Eugen Dühring, and Édouard Drumont and, in fact, their works were discussed and even serialized in Rola. While Jeleński showed restraint in commenting on contemporary "ritual murder" trials (in particular, the blood libel accusation and trial of Tiszaeszlár in the early 1880s), in most ways his attitude toward Jews was not really so very different from that of the contemporary Catholic Church. The main difference in the pre1905 period lay in the contrast between Jeleński's brash and even vulgar activism and the Church's more subtle teachings that Catholics should avoid contact of any kind with Jews.

Moszyński ably brings the story up to the eve of World War I, discussing the general radicalization (and lurch to the nationalist right) of Polish politics in the wake of the failed 1905 revolutions, contrasting Jeleński's brand of judeophobia with that of the National Democrats, and explaining how the Duma elections in this decade fomented anti-Jewish attitudes. Here specialists will find little in the way of new argumentation or concepts, but these developments are well analyzed and developed on the basis (mainly) of contemporary press. After 1912, as Moszyński demonstrates, antisemitic politics dominated in Warsaw and the Russian partition with an almost total breakdown of normal relations between Poles and Jews living there. To be sure, perhaps these tensions would have eased with time, but in fact the outbreak of World War I simply swept this problem under the proverbial rug, to be dealt with—or not—by the Republic of Poland from 1918.

While Maciej Moszyński provides a fairly traditional (though admirable) historical narrative of the development of modern antisemitism in the Kingdom of Poland, Małgorzata Domagalska's Zatrute ziarno [The Poisoned Seed] has a quite different purpose. Domagalska aims to analyze 
the tropes used by writers in Rola in fictional accounts of Jews. This study thus somewhat overlaps with Moszyński's (the use of Rola, the concentration on Warsaw), but Domagalska uses literary analysis and fiction to make her point. Thus, these two books nicely supplement each other, the one setting down the political and ideological developments, the other demonstrating how literary images and tropes reflected the development of antisemitism in these years.

Domagalska begins her study with an overview of scholarly literature on Polish-Jewish relations in this period and a sophisticated discussion of Jeleński and his weekly publication. Having set down the main topics and contours of Jeleński's brand of judeophobia, she goes on to analyze a number of specific topics that appear in the literary works published in Rola. These stories and serialized novels reflect a number of stereotypes about Jews: as unproductive and exploitative ("spiders" to hapless Polish peasant "flies"), beasts of prey, moneylenders, and village innkeepers. Of course, the figure of the Jewish tavern keeper is indeed a figure taken from life, and no doubt—like bar owners everywhere-many of these entrepreneurs encouraged locals to drink (and to spend money on booze) more than was good for them. In these literary portrayals, however, the tavern becomes the site of tragedy, where a good-hearted (but, it is understood, rather dull-witted) Pole falls into bad habits, takes out loans to pay for vodka, neglects his family and, inexorably, is ruined. It goes without saying that in such portrayals, the reader is encouraged not to bemoan the human weaknesses of the peasant alcoholic but to blame everything on the Jewish tavern keeper.

Some of these literary works were not devoid of merit. In particular, the writer Klemens Junosza-Szaniawski integrated considerable actual knowledge of Polish village life into his stories. While hardly favorable to the Jew, Junosza also depicted the "darkness" (backwardness, illiteracy, lack of culture) that prevailed among Polish peasants. Jews appeared in his stories as a natural and even unavoidable part of the Polish countryside, rather as Alina Cała has shown in her work on (much later) Polish peasants' attitudes toward Jews. While the Jews are certainly portrayed negatively, Junosza (rather unlike Jeleński) does not romanticize the Polish peasant. And, on the whole, these writers could hardly portray strong, intelligent Polish peasants since such character traits would allow them to avoid exploitation at the hands of the Jews. Rather like socialist realism, the Jewish writers in Rola portrayed the Polish countryside as the 
site of social conflict that could only end with the triumph of the good-in socialist realism, the party, and in these literary works, the Polish nation.

Domagalska successfully analyzes these probably rather dreary stories and novellas in such a way as to make them seem quite interesting-but probably most readers of her book will thank her that we do not have to slog through them ourselves. Several aspects of these works are apparent, among them, paranoia, pessimism, a belief in conspiracies, and a rather illogical (given the portrayal of Poles as mainly people lacking intelligence, culture, or discipline) belief that the good (i.e., the Polish nation) would triumph in the end. The paranoia comes through in the numerous Jewish characters who succeed at breaking through caste boundaries and aping the (erstwhile) ruling class, the szlachta. While these Jews are mocked for their bad Polish, accents, poor taste, etc., one comes away with the uncomfortable feeling that they must, after all, have certain talents that enable them to succeed so frequently. This realization, perhaps, feeds the pessimism reflected in the numerous tragedies that befall the Polish heroes of these stories, their inability to compete with Jewish rivals, and the general feeling that maybe the Jews are, after all, a superior race.

But, of course, this cannot be the case! The triumphs of the Jews are, naturally, only a temporary epiphenomenon and owe much to their evil nature and to conspiracies that support that evil. Thus, discovering and unveiling these conspiracies (which in many ways come down to "the modern world"-modern banking, journalism, university study, capitalism...) will defuse the power of the Jews and pave the way for the good. To be sure, the rapid rise of a Jewish capitalist class in the second half of the nineteenth century, exemplified by such families as Bloch, Wertheim, Wawelberg, Kronenberg, and Natanson, could well make a simple Polish peasant (or petty bourgeois, like Jan Jeleński) believe in conspiracies. While many ethnic Polish entrepreneurs, bankers, and industrialists were also amassing considerable riches in these years, the formation of a Jewish moneyed class was new-and to readers of Rola, threatening. Rather than looking at the complicated economic and sociological factors leading to these changes, a belief in conspiracies both neutralized arguments that Jewish talent made them rich and offered an easy solution: discover the conspiracy, root it out, and Poles will flourish.

Many of the literary pieces published in Rola, Domagalska makes clear, were not particularly weighty. Indeed, satires and humorous sketches were predominant among them. And, after all, what is more amusing 
than mocking the nouveau riche? The incongruity of individuals born as traditional Jews attempting to present themselves as szlachta did not have to be invented by the Rolarze; this was a real phenomenon that held considerable humorous potential. However, this was humor with an edge: while the overdressed and vulgar Jews (in particular, Żydówki) could be mocked, the stories posed the obvious question of why Poles were not similarly advancing in wealth and status. (They were, of course, but economic and sociological realities played only a minor role in the development of Polish—and other-antisemitism.) Thus, while offering light entertainment, the stories had a serious purpose of "warning Poles" to strengthen their own nation in order not to be swallowed up (a constant metaphor among antisemites) by ambitious and unscrupulous Jews.

Perhaps the best-known dystopia of a Jewish-dominated "PolskaPalestyna" is Julian Ursyn Niemcewicz's Rok 3333, czyli sen niestychany [Year 3333, or an Unbelievable Nightmare], that portrays a Warsaw under the rule of "Moszek XII." After 1905, as Domagalska shows, such dystopic portrayals of the future cropped up frequently in Rola. Indeed, this negative vision of the future allowed Jeleński and company to argue that quick and energetic measures against the Jews had to be taken at present. This warning was repeated in a serialized novel, Warszawa 2000, that appeared in Rola in the first years of the twentieth century. Portraying a Poland that has been enslaved by the Alliance Israélite Universelle, the Rothschilds, and other usual suspects, the present dismal state of the ojczyzna (fatherland) is evident in the replacement of proper Polish aristocrats by Jewish parvenus with such sonorous family names as Szpak, Tłusty, and Markotny. Happily, a resistance movement led by Polish immigrants to the USA and headed by the improbably-named John Armstrong-Podhajecki leads the forces of proper Catholic-infused polskość (Polishness) to victory.

$* * *$

Małgorzata Domagalska's study of literary reflections of antisemitism is particularly valuable in showing how judeophobia took on a variety of everyday forms, transforming prejudice to humor, amusement, as well as protest. Grzegorz Krzywiec's new book, Polska bez Żydów [Poland without Jews], returns us to the arena of politics, concentrating on the "ideas, concepts, and practices" of Polish antisemitism in the period between 1905 and the outbreak of 1914. Building and expanding on his earlier work on Roman Dmowski, in this book Krzywiec offers us a detailed and in-depth 
look at a decade which was of crucial importance for the formation of modern Polish antisemitism.

The chronological boundaries of Krzywiec's Polska bez Żydów are delineated by a revolution and the outbreak of a war which would lead to an even more shattering upheaval in 1917. Before the 1905 revolution antisemitism as a political belief and movement was small and rather despised by Polish educated society. To be sure, Jan Jeleński's Rolaas we have seen-have been around for two decades and the National Democratic Party had already gone from implicitly anti-Jewish to fairly explicit antisemitism. By the outbreak of World War I, Polish society was quite united in antisemitism. While some liberals-and nearly all socialists-continued to defend Polish traditions of freedom and national integration of the Jews, Polish society in its majority had jumped on the bandwagon of anti-Jewish rhetoric and practice, including during the boycott that began in late 1912. Such erstwhile liberals as Iza Moszczeńska, Andrzej Niemojewski, and Aleksander Świętochowski joined the chorus of judeophobia. And the Catholic Church, which had always expressed disdain (or worse) for Jews and counseled the faithful to avoid Jews, in these years drew closer to the antisemitic political movements, in particular Narodowa Demokracja (National Democracy, henceforth "ND"). It is this period that Krzywiec analyzes in sophisticated detail.

Like many before himself, Krzywiec sees the 1905 revolution as a "trauma." At the beginning of the upheaval, many Poles hoped for educational reforms, political concessions, even autonomy for the Kingdom of Poland (officially, the "Vistula Land" but the pre-1863 designation was still widely used, even in official documents). Alas, all of these hopes were dashed by the end of the year. By late spring of 1905, after the Russian authorities had conceded an expansion of freedom of religion (i.e., the right to convert out of Orthodoxy to other Christian denominations, including Catholicism) and censorship was more or less eliminated (at least in practice), conservatives began to denounce the revolution as socialist and "anti-Polish." With the suppression of the revolution in 1906 with few serious concessions to Polish culture (much less any type of autonomy), the conservatives turned their anger and frustrations on the progressive and socialist camp, which they increasingly identified with Jews.

While this general narrative is quite well known, Krzywiec deepens and complicates the story with numerous little-known events, such as the murder of conservative writer and editor Jan Gadomski (during a robbery) 
in late 1906. "The case of Jan Gadomski" (sprawa Jana Gadomskiego) allowed conservative forces to equate the revolution with banditry, chaos, anti-Catholicism, and-of course, the Jews. Even Henryk Sienkiewicz, who despite his conservative views generally avoided explicit judeophobia, reflected this trend, as Krzywiec shows.

The trauma of 1905 also deeply affected the Catholic Church in the Kingdom of Poland. The attempt to create a Catholic political movement here ended in failure with the would-be political Catholics going over in mass to support for Dmowski and company. Of course, it was natural for conservative Catholics at the time to see in the Jews a dark and sinister antiPolish force. But the actual events of 1905, in which Jews were quite visible in strikes, socialist protests (whether Bund, PPS, or SDKPiL), caused what Krzywiec terms a "moral panic" among traditional Catholics. The fruits of this trauma are best seen in the creating of organizations for Catholic workers and the founding of Polak-Katolik, a daily that explicitly mentioned in its prospectus the battle with Jewish forces (p. 114). Thus by the time of the elections to the Third Duma (1907), the stage was set for the rapid shift to a near total victory of antisemitism within Polish society in Warsaw and the Kingdom of Poland.

The context of this shift was, as Krzywiec admirably describes, a feeling of crisis of Polish culture/politics and a growing identification of Jews as the cause for all problems. The traditional/liberal view (shared also by such conservatives as Erazm Piltz and the readers of $\mathrm{Kraj}$ ) of the integration of Jews into the Polish nation, the so-called Żydzi-Polacy (Jews-Poles, i.e., assimilated Jews), fell into disrepute quickly after 1905. A "hero" of Krzywiec's earlier work, Julian Unszlicht (pseud. Sedecki), nicely exemplifies the elimination of acculturation as a real alternative for most Poles. Unszlicht, born in a Jewish family, first published his antisemitic diatribes (especially against the SDKPiL) under the less Semitic-sounding pseudonym "Sedecki" but after having been "outed" argued vociferously that Jewish birth did not automatically put one outside the Polish nation. However, Unszlicht vehemently insisted that all links with one's community of birth must be cut off, indeed, the ex-Jew must become a $150 \%$ antisemite in order to join the Polish nation (conversion to Catholicism was also expected). The unusual path followed by Unszlicht-Sedecki from socialism to the Catholic Church may be seen as a reflection of the general moral panic of these years which saw Jews as enemies, revolutionaries, and invaders who threatened Poland, Catholicism, and worked to install "Judeo-Polonia" in place of the ruins of Catholic Poland. 
Another important context was the increasing perception among Poles that masses of Jews, speaking a kind of East Slavic jargon, were pouring into the Kingdom of Poland. The so-called litwacy ("Lithuanians," i.e., Jews coming from the interior of the Russian Empire) thus brought together Polish fears of Jewish plots with dread of Russification and cultural extinction. Despite its lack of factual foundation, the "litwak invasion" lent credence to dark forebodings on the part of Catholic-Judeophobic-ND propaganda. Thus, when during the elections to the Fourth Duma, Jewish electors in Warsaw refused to support the ND candidate who, while not personally antisemitic, refused to support Jewish equal rights, the worst fears of Polish judeophobes appeared to be coming true. Wealthy Warsaw Jews electing a Polish socialist to the Duma seemed to corroborate predictions of "Judeo-Polonia." The anti-Jewish boycott of late 1912 was the result.

While some scholars, such as Robert Blobaum, have pointed out that the anti-Jewish boycott was in fact not very effective economically, this argument rather misses the point. The boycott was exceedingly effective in setting up a mentality by which Poles and Jews were utterly different, separate, and hostile. Krzywiec traces the development of this ideology by examining the contemporary writings of Zygmunt Balicki, Stanisław Pieńkowski, Teodor Jeske-Choiński, as well as the different "flavors" of Polish antisemitism ("nationalist," "progressive," "Catholic-national") and the main press organs of this newly aggressive antisemitic movement in these crucial years to August 1914. We will never know, of course, whether the anti-Jewish fervor of these years might have died down had the war not come. Unfortunately, many of the tropes, images, and imaginaries of these years would crop up after 1918 and far into the future.

Historically, Poland has been home to an enormous Jewish population. In the modern era, when "nationality" and "ethnicity" took on huge importance in ordering society and politics, one could predict that the cultural-national difference between Jews and Catholic Poles would lead to frictions. In particular, in the repressive and anti-Polish context of the Russian Empire, these frictions were considerably exacerbated. These three new works on the makings of modern Polish antisemitism, all based on extensive research and admirable historical and literary analysis, can help us understand how traditional religious judeophobia was transformed 
into a modern political movement. For anyone interested in Polish history, the history of ethnic/racial prejudice, and Jewish history in East-Central Europe, these books are recommended.

Theodore R. Weeks Southern Illinois University, Carbondale 